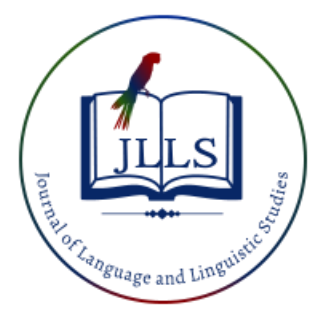

Available online at www.jlls.org

JOURNAL OF LANGUAGE

AND LINGUISTIC STUDIES

ISSN: 1305-578X

Journal of Language and Linguistic Studies, 17(4), 2081-2095; 2021

\title{
The pragmalinguistic character of intonation units in discourse
}

\author{
Bazarbayeva Z. M a 1 iD, Amanbayeva A. Zh ${ }^{\mathrm{b}}$ iD, Zhumabayeva Zh.T ${ }^{\mathrm{c}}$ (iD), \\ Zhalalova A. $\mathrm{M}^{\mathrm{d}}$ iD \\ ${ }^{a, b, c}$ Institute of Linguistics named after A. Baitursynov, Kazakhstan \\ ${ }^{d}$ Kazakh National Women's Teacher Training University, Kazakhstan
}

\section{APA Citation:}

Bazarbayeva, Z. M., Amanbayeva, A. Zh., Zhumabayeva, Zh.T., \& Zhalalova, A. M. (2021). The pragmalinguistic character of intonation units in discourse. Journal of Language and Linguistic Studies, 17(4), 2081-2095. Doi: 10.52462/j1ls. 150

Submission Date:13/06/2021

Acceptance Date:28/09/2021

\begin{abstract}
Speech discourse is the communication between people, that is, the speaker seeks to influence the recipient in a conversation, using deep thoughts and meaningful words, expecting to receive a response from the addressee. In modern Kazakh linguistics, speech discourse is being explored in various ways as a reflection of people's relationships and actions. This research aims to study intonation of the text in the form of official radio interview and to reveal pragmalinguistic peculiarities of it. We used methods of audit, experimental and electro-acoustic analysis for this research. In the article, speech discourse is analyzed pragmalinguistically and its intonation features are investigated by experimental research. Consequently, we took unprepared speech for experimental research, where the participant of interview was informed about the topic of the conversation. However, despite the fact that the theme of the issue was given, the discourse in the form of a previously unprepared radio interview is provided as the subject of research. Among other findings, the results of the study showed that it is advisable to use appropriate pauses, especially the pauses of hesitation, while speaking.
\end{abstract}

Keywords: intonation; prosody; intoneme; pause; discourse; verbal communication

\section{Introduction}

It is known that the problems of speech discourse in general linguistics have recently been studied in various aspects, and a number of issues are also being studied in Kazakh linguistics (Gizdatov \& Sopiyeva, 2018). Therefore, speech (verbal) communication has been found to be very powerful in language, as it is a communication base (Deacu, Kilyeni \& Barbulescu, 2018). Speech (verbal) communication is a free, unprepared speech that reveals the role of the human factor.

The communicative function of a language implies the communicative function of the individual language units, integrating them with extralinguistic factors. Foremost, communication is the interconnectedness and interrelationship of people (Minyar-Beloroucheva, Sergienko, Vishnyakova, \& Vishnyakova, 2020). The field of communication has its own purpose. For instance, a linguist teaches how to speak, an economist teaches ways to save (money), medicine teaches how to treat a patient, and philosophy explains the meaning of life. Thus, the vocabulary of each field is formed, and then it helps

\footnotetext{
${ }^{1}$ Corresponding author.

E-mail address: bazarbayevaz.m@yahoo.com
} 
to form its own environment, that is, the corresponding discourse. And in order to provide the discourse, the message needs to be clear and understandable, so it is necessary to convey the idea precisely.

Today many thoughts and opinions have been put forward about the speech process in the development of linguistics. In particular, the famous German linguist Humboldt (1999) wrote: "Speech is boundless and diverse in relation to thought. There are units of language that regulate it, but they systematize certain types of communication within this boundary." (Humboldt, 1999; Korolyov \& Domylivska, 2020). Klyuev (1988) claimed: "Speech is, first of all, a necessity in initiating a communicative act,". Maksimov(2000) stated in his work: "Oral speech has such an intonational variety of speech that it can convey the whole wealth of human feelings, emotions, moods", and it means speech clearly reveals the inner qualities of a person and clearly expresses feelings, moods and anxieties through intonation.

Baitursynov (1992), one of the founders of Kazakh linguistics, pragmatically stated the purpose of speech in his work: "Speech is to convey a message to another person. Every person expresses his idea and thoughts by speaking and writing. Not all spoken words are sentences; only words that are comprehensible to the speaker can be sentences" (Baitursynov, 1992; Zhumanbekova, Bentyaa, \& Dzharbulova, 2018). At the same time, speech is primarily caused by the need to start a communicative act. Communication is established through speech, and it affects the listener, then speech communication is carried out. That is why the theory of speech communication, or the speech act is now being considered as a new direction in linguistics. Linguistic pragmatics is the science of the correct language use in the process of communication as the basis of the speech act (ZandMoghadam \& Adeh, 2020). It deals with the communicative use of language. On this basis, the use of speech communication can be illustrated as follows: Speech communication $\rightarrow$ addresser $\rightarrow$ connection $\rightarrow$ referent $\rightarrow$ code $\rightarrow$ addressee.

As a matter of fact, the basis of verbal communication is the exchange of information, whereas intonation plays a special role in the realization of the pragmatic goal (Lukyanova \& Koloskova, 2020). The mood and background knowledge of the person can be clearly traced through the intonation (Astuti \& Chandra, 2021). His speech can reveal his personality and his attitude toward life. In general, if the discourse is not prepared, it is possible to notice intonation differences and even to see if the orthoepic regularity is preserved (Uzunboylu \& et. all, 2015).

In this regard, we believe that the results of the research will influence the addresser (sender) and addressee (receiver) for using the word intonationally correct and will have an intonation effect on the audience, eliminate gaps in unprepared speech, as well as enable the stage actors to correctly understand the intonation of speech. Experimental studies have shown that the inability to pause properly interferes with the understanding of the listener (Yeldham, 2018; Calandruccio, Porter, Leibold \& Buss, 2020).

\section{Literature Review}

A person is always in the process of thinking, even when he is sleeping (Natividad \& Batang, 2018). This provides evidence for the fact that thinking, and speech are closely connected. Matzler (1970) states: "If a language is a tool used as the subject of communication through thinking and perception, then speech is the way of expressing thoughts. Language and speech never contradict each other, on the contrary they supplement each other, providing different speech acts between people". Therefore, thoughts formed in the human mind are expressed with the help of language. In the human mind, the sequence of words is systematized in its own meaning and transmitted from sender to recipient. If the word is not systematized, it will be incomprehensible and scattered. The sender tries to 
choose the right meaningful word so that it will be clear to the recipient. Vygotsky (1934) writes: "Speech is transformation of thought into word and speaking makes new ideas appear". Lvov (2000) points out: "Speech takes place when people communicate with each other, share opinions, inform about something" and gives three meanings:

1. Speech is an action (performance).

2. The result of a speech action and its expression is a word.

3. Speech is a rhetoric genre (Lvov, 2000).

Thinking requires understanding, being at the same time the basis of understanding. Speech and communication are only realized when the concept is understood (Mok, 2010). The basis of communication is provided by thoughts (logic), psychology, words. That is why, first of all, a man thinks about his own vocabulary and background knowledge, his experience and then transmits it to the second person, and this is called the locutive act (Al-Eryani, 2007; Kavilova, Umrzoqova \& Inomov, 2020). A person uses language symbols not only for mutual understanding but also to arouse interest in an opponent (listener). Language units are recognized not only as message providers, but also provoke listeners to act. Consequently, speech is closely related to the speaker's thinking, so the meaning of his words is of particular importance. The speech is formed as a dialogue, which is realized in three different communicative directions. They are a speaker and a listener, situation and place of speech. In this regard, Bazarbayeva et al., (2015) emphasized the place of intonation components in speech. Another quality of the conversation is its expressiveness, and undoubtedly the expressive speech is pleasing to the ear. In fact, when we do not say each word in its own way, our words become obscure and cannot be fully understood; hence, the speech process is different in voice. Especially loud voice is sometimes needed to express one's opinion, and it sometimes is used to draw listener's attention. Along with the semantic meaning of the spoken language, the sound, the intonation, the voice and the diction play an important role. In speech, intonation expresses thoughts and emotions of the speaker. Moreover, such additional uses as gestures, mimics complement the idea (Bazarbayeva et al., 2016; Mavasoglu, 2018).

In speech, we use all possibilities of the language, the richness of the word, and the intonation effect. Psychology has found that $60-80 \%$ of human communication is verbal and $20-40 \%$-nonverbal. According to linguists, only $35 \%$ of information is carried out by language and $65 \%$ - by non-verbal tools and techniques. (Grushevskaya, Popkov \& Sadokhin, 2003)

Every speech act aims not only at informing the listener but requires an understanding of each other's response to his or her opponent's perception, and also influences on one's inner sense of surprise, annoyance, or rejoice. When a word is used orally in speech, rhythm and intonation play the roles of communicative markers. In speech, however, the word is not only a notion, but also meaning, feeling, and thought. Therefore, words that are meaningful and appropriate should be linked to each other in the sentence. Goikhman \&Nadezhdina (1997) state that thoughts and speech are interrelated in their work on speech communication: "The most important function of speech as an activity in the process of communication is the function of the thought expression. A man always thinks, except for complete rest and deep sleep. Speech is inseparable from thought ... To think is to operate with concepts. To think, you need to know the words denoting these concepts" (Goikhman \&Nadezhdina 1997). 


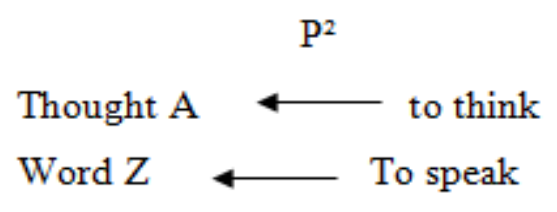

Figure 1. The process of speech

Therefore, thinking comes from thought, while speech is formed from word. However, thinking is not only the basis of speech communication, but also the essence of humanity throughout the entire speech process. Thus, thinking and mind, language and speech are inseparable phenomena.

The most important process in language communication is speaking and communicating.

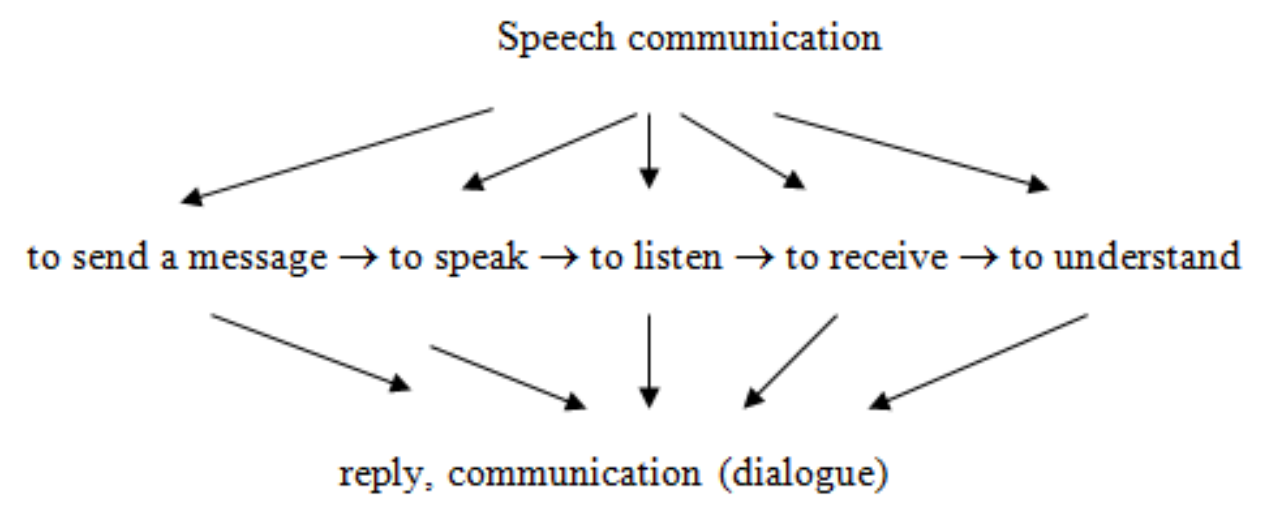

Figure 2. Representation of Speech communication

Speech serves a person to affect his purpose in any situation. Without speech, there is no communication between people. There are three main types of communication: first, -the speaker, then - the listener, and the third, - the speaking situation and place. During the conversation, the communication between specialists in different fields will be different. For example, communication between professionals in the same field (a philologist with a philologist, a chemist with a chemist, etc.) can deal with the subject of their interest, and there will be no communication between specialists in different fields. For example, language communication ceases when a philologist talks to a chemist about his field. This is since experts in each field have their own terms and principles in the speech system (Legas \& Mengistu, 2018; Khajayeva et al., 2021). Only everyday communication (family, life, status) can be the subject of communication. The speech is emotional, pleasing to the ear, in case of its tuneful expression, the emotional expressiveness of the speech depends on the emotional expressive state of the person.

It is well-known that the process of speech is structured and communicative through the influence of intonation and demonstrates semantic unity. Eight different intonemes of the Kazakh language, depending on the structure and relation of intonation, were revealed. They are: 1 . accurate intoneme 2 . inaccurate intoneme 3. general question intoneme 4. special question intoneme 5. strict imperative intoneme 6. polite imperative intoneme 7. explicit sentence intoneme 8 . introductory segment intoneme (Bazarbayeva, 2016). These units have a special effect on the identification of the multidimensional phenomena of intonation used in free unprepared speech. Especially all types of intonemes are involved in the dialogic language (Bazarbayeva, 2008; Theodorou \& Meliones, 2019). 
The invariants and variants of intonation units can be observed in speech and have different character (Bazarbayeva, 2012; 2014). With reference to it, "Phonetic variants are difficult to distinguish. It is because the sound variants of the word are formed not only by the accents, the influence of another language, but also by orthoepy, simple spoken language and even the specifics of the individuals' speech." (Bizakov, 2000). Due to this, intonemes are detected during unprepared speech. The sentence itself consists of accurate and inaccurate intoneme. If in the middle of a sentence there is an unfinished form of thought, it will be completed with a final intonation at the end of the sentence. In the speech act, inaccurate intoneme is distinguished by the ascending tonal line and the mid-tone range, whereas the accurate intoneme is characterized by the lower tone range. (Bazarbayeva, 2018).

Accurate intoneme: (figure 3) - these syntagmas are expressed in accurate intoneme by ascending and descending from the third tonal contour, because the sender expresses the important point at the end of the sentence, emphasizing it. Especially, the pace of intonation is accelerated at the end.

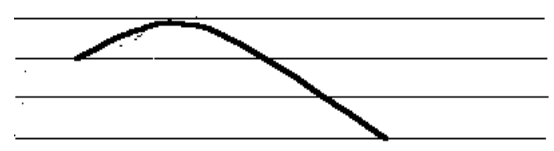

Figure 3. Accurate intoneme

Inaccurate intoneme: Solarga tikelei kirip aitsam | sengimsin? deit. Meninshe oilaim, | osy myna arbir kazakhtyn azamaty | osyndai gatelikterbi, | shyn maninde ozi | gorop turgan katelikter bolsa | baryp, | meninshe aitugerek syakty (135-150Hz).

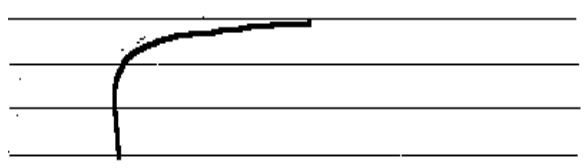

Figure 4. Inaccurate intoneme

The last word of the inner syntagma of this sentence is accentuated, and the next word indicates the continuation of the thought, which demonstrates that it is made by inaccurate intoneme. Inaccurate intoneme occurs at the beginning and in the middle of the speech act. At the same time, the tone increases rapidly, and the tempo is quick. (Amanbayeva, 2012).

Special question intoneme: Osy syakty tagy | «Fotokuzhat» dep | zhazypkoigan zherler bolt. Solarga tikeleigirip aitsam | «Sen gimsin?» deit (140-95Hz).

The intonation can have a strong influence on speech pragmatically and communicatively. For example: «Sengimsin? deit» - here the sender is pragmatically conveying the intent to express his opinion by presupposition (it means: how dare him that I came from language department?). This intoneme rises from the third tone level to the fourth level and fades again. 


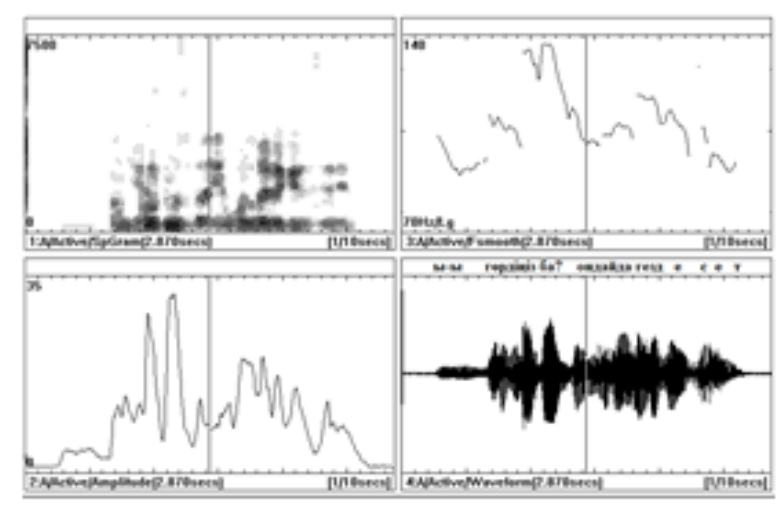

Figure 5. Special question intoneme

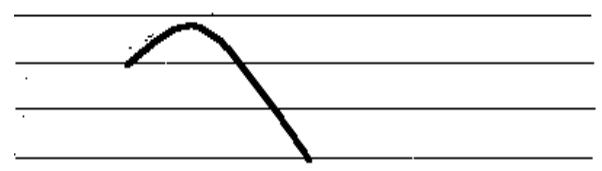

Figure 6. Hesitation pauses

General question intoneme: A, mynau Temiryazev koshesinin boyinda | bir dukonge zhazyp koigan eken | shuzhiktar dep zhazypkoyipty. Err... gurdiniz ba? ondai da gezdeset (Figure 7).

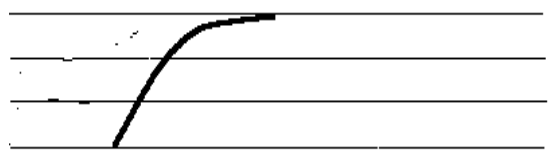

Figure 7. General question intoneme

These intonemes are made with a slightly curved line, rising from the first tone contour to the fourth. There is no significant difference between these syntagmas, and it is observed that the intonation is higher due to $(m a, b a)$ conjunctions. And in this syntagma "Err... gurdiniz ba?," the hesitation pause can be observed. The sender paused in order to ponder his next word which usually occurs during unprepared speech (Amanbayeva \& Zhumabaeva, 2017 ).

Polite imperative intoneme often not only reaches the recipient but also aims at fulfillment of request. Wish, asking, request prevail here rather than strong request, strict command or demand as in strict imperative intoneme. The invariant of the polite imperative intoneme rises from the second level, reaching the third tone. It is characterized by upward convex line. For example: Aitugerek syakty, bastau gerek koi, artyk gyzmet atkaruigerek - here doubt, address to somebodylsomething differ in polite imperative intoneme invariants.

Polite imperative intoneme: Sonda garanyz? | meninshe oilaim | osy myna arbirgazakhtyn azamaty $\mid$ osyndaigatelikterdi $\mid$ shyn maninde ozi $\mid$ gorip turgan gatelikter bolsa $\mid$ baryp $\mid$ menimshe aitugerek syakty $(115-140 \mathrm{~Hz})$. 


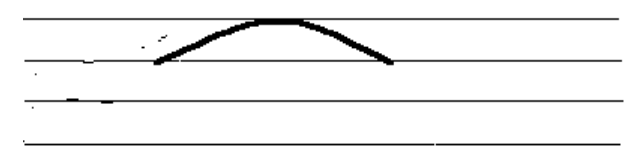

Figure 8. Polite imperative intoneme

In this unprepared speech, strict imperative intonation is rarely encountered in words. Strict imperative intonation is characterized by a sharp decrease from the fourth tone to the first. This is because the strict imperative intonation dictates the mandatory execution of a command. In the speech act, the addressee says "Ony tekserugerek!", demonstrating the strict imperative intoneme.

Strict imperative intoneme: Ony tekserugerek!

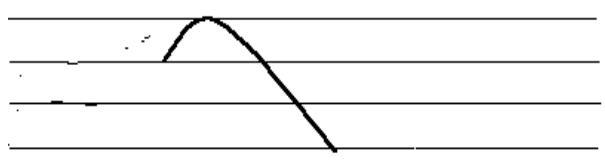

Figure 9. Strict imperative intoneme

The next unit is introductory segment intoneme. Short segments indicate meaninglessness in unprepared speech. In speech, the invariants of the intoneme are transformed, decreasing from the third tone contour to the second convex, and sometimes even in a straight line. For example: "Zhana aitpahshy”, "mynadai zhanagy", "meninshe aitu gerek syakty”, "zhanagy oziniz aitpahshy”, "nemese zhanagy». These short segments are only ancillary to speech $(19, \mathrm{p} .86)$.

\section{Introductory segment intoneme:}

Dzharnama degen | zhanaitpahshy | otegurmeuigop | masele bop otur. Sizdin bul pikirinizben | men kosylalmaim | seebi | bul bayagygezden | kazirgi gez ozgeshe | bayagy koshege shygyp | koringen tastyn ustine shygyp aigailap | nemese zhanagy baibalam salatyn uakyttan ottik (100-100Hz).

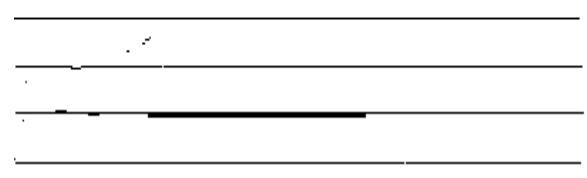

Figure 10. Introductory segment intoneme

\section{Explicit sentence intoneme: Rahmet!}

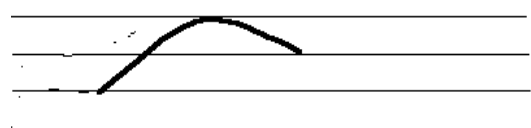

Figure 11. Explicit sentence intoneme 
In unprepared speech, the pragmatic purpose is effected, the idea is completed and precision of opinions is determined through intonemes. Experimentation has shown that intonation is a phenomenon that serves as a way of getting the meaning within the unprepared word stream.

\section{Method and Materials}

There are two opposite sides of the communicative act. For example, (message) sender - (message) receiver, writer - reader, speaker - listener, addresser - addressee. In this regard, the speech communication is divided between addresser and addressee, text communication is divided between author and reader. This is since the addresser and the addressee communicate verbally through speech communication, and the written form indicates the relationship between the author and the reader through the text. That is, the author influences the other person through the text, he contributes to the emergence of new perspectives and the expansion of knowledge, while discourse influences directly through speech communication. Consequently, discourse is the communication through the act of speech and, if so, its solution, text is a linguistic field of knowledge in the language system. Due to this, Arutyunova (1990) states: "Discourse is a coherent text in combination with extralinguistic, sociolinguistic, psycholinguistic and other factors; the text taken in the eventual aspect". In the 1960s and 1970s, discourse was considered merely as a connection between sentences or speech acts, but then it expanded, encompassing complex communicative relationships as well as communication through the extralinguistic factor (cognition of the world, worldview, point of view). Each speech (oral and written) has a certain system in it and a basis for speaking (Joudi, 2019). Therefore, there are several functions within the language: firstly - sending a message; secondly - an agitation, initiating a case; thirdly - the influence of feelings (Goikhman \& Nadezhdina, 1997).

From the pragmatic point of view, discourse can be considered as a connection with semiotics of Morris, that is semantics, syntactic, pragmatics (Posner, 2019). To start the discourse, we need to find the language code mechanism. For this purpose, it is necessary to form the field of knowledge (background knowledge - Ualiyev as cited in Bazarbayeva et al., 2014), the extralinguistic factor. Discourse can also be seen on the theater stage, where the actors play roles by memorizing and telling the finished text, affecting the listener. In fact, discourse is really formed on the theatre stage, being the dramatic discourse.

During the research, components of the text such as melody and rhythm, tempo, pause, tonal band were analyzed separately based on the recorded text as an interview. The tone can be rise-fall, fall-rise, rise, fall; the intensity of tone can be increased, decreased and tempo can be fast-slow. According to the type of tone, the pause is divided into three levels: short, middle, long. The tonal range is divided into wide and narrow type. At the same time, the melody and the intensity are used together, because they are often used in parallel. An experimental analysis of unprepared speech is now being carried out on this basis, and it is pragmalinguistically described.

Nowadays radio and television are as a source for broadcasting, and among the radio broadcasting programs we took the unprepared talk and interview speech intonation as the research object. Although the interview topic is free, it expresses itself within the framework of a common topic and uses well-reasoned examples for discussion. The main topic of the conversation between the announcer and the commentator is the current language issue and street advertising with mistakes. Dialogues were recorded on six audio tapes via the radio over the line. Among them, we selected the following topic: "The current state of the Kazakh language or how to correct the mistakes of the advertisements and billboards?" The tape was scanned on an oscillogram, and auditory and instrumental analyzes were performed. 
The objectives of auditory analysis were as follows: the speech syntax between the lines is marked by a vertical line $(\mid)$, between the phrases is marked with a double vertical line $(||)$; to mark the pause in the phrase with a dash $(-)$; a sign of hesitation pause $(\sim)$; to mark graphically the basic tone line of the segments; the movement of the basic tone frequency is reflected in five different directions: rise $\uparrow$; fall $\downarrow$; mid-level $\rightarrow$; fall-rise $\downarrow \uparrow$; rise-fall $\uparrow \downarrow$; to determine the intensity of pronunciation of segments.

The tempo is marked as below:

- Slow

- Middle

- Fast

Determination of the pitch of the voice:

- Increased <

- Decreased >

The results of auditory analysis (fragment)

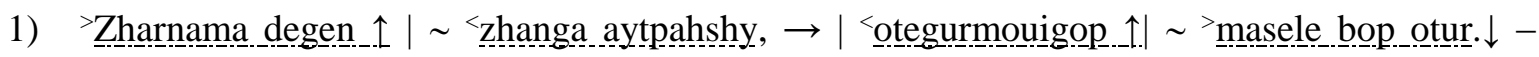

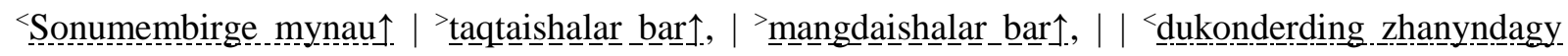

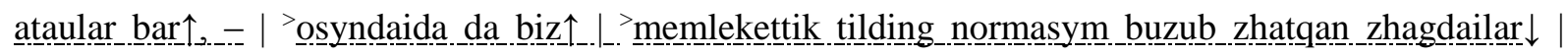

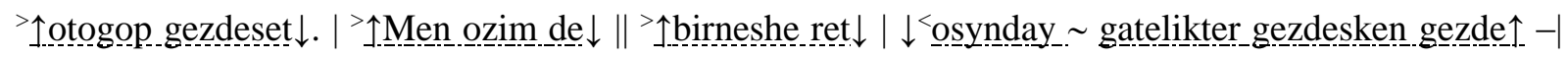
`^sol mekemege turagirip baryp $\downarrow \mid$ 'aitkangezderim de bolt $\downarrow \downarrow \sim \mid$ '^A, mynau $\downarrow, \mid$ 'Temiryazev

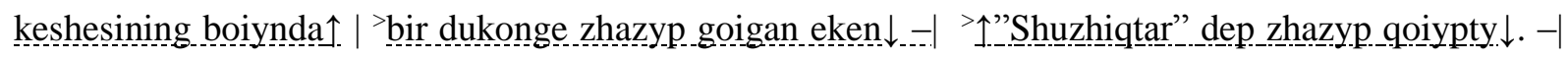

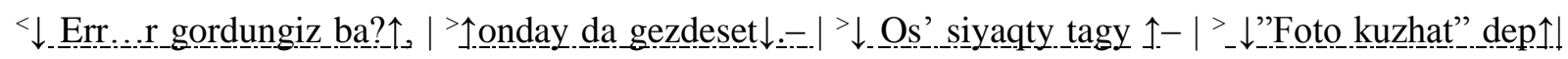

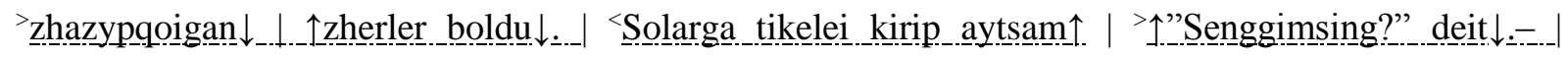

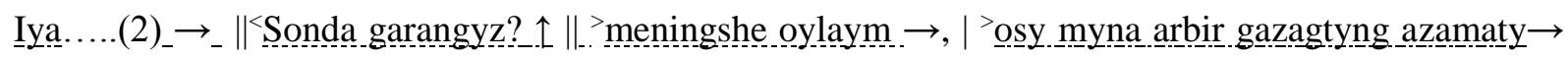

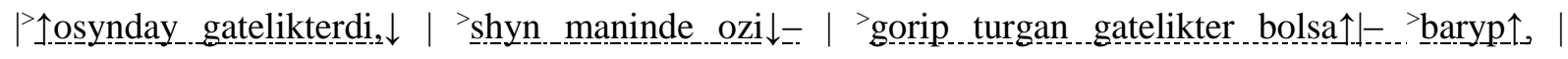

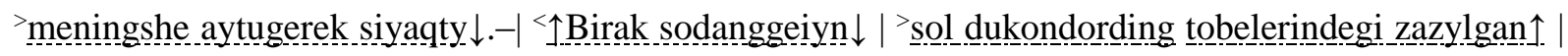

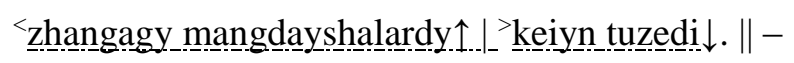

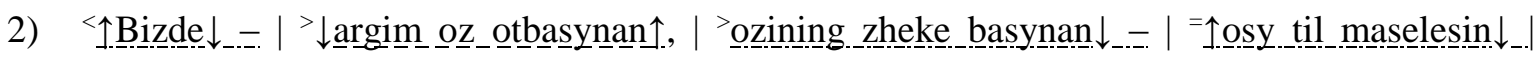

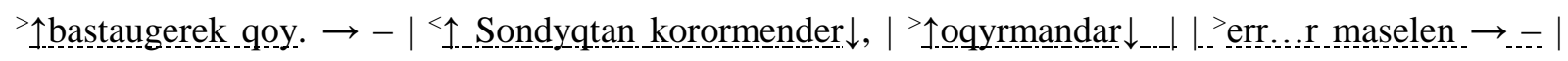

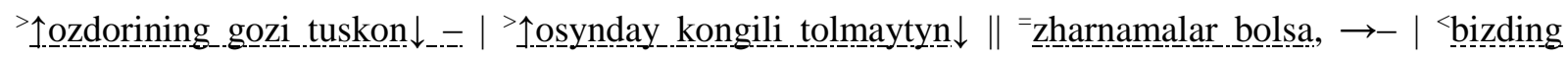
galalyq «Til basqarmasyna»^ - | 'myna zhetpis bir $\uparrow-. \mid$ 'alpys bes togsan degen telefondaryna $\rightarrow \mid$

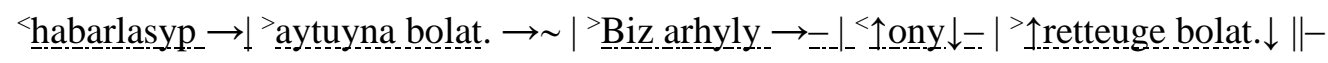

\section{Results}

In modern Kazakh linguistics intonology is being studied in different aspects. Therefore, this article focuses on intonation in pragmalinguistic aspect. Since the intonation became the object of study in Kazakh linguistics, its structural aspect, system and language units have been defined. However, its functional and structural aspects and problems of anthropocentric linguistic science in the field of cognitive science have not been fully studied. The article examines the pragmatic aspects of language facts during unprepared speech. The flow of speech during unprepared speech is studied from pragmatic aspect, and it is obvious that the components of intonation - melody, loudness, tempo, pause, pitch, and tone play a particular role in performing the pragmatic purpose of speech. Kazakh intonation units such as accurate intoneme, inaccurate intoneme, general question intoneme, special question intoneme, strict imperative intoneme, polite imperative intoneme, explicit 
sentence intoneme, introductory segment intoneme have been investigated pragmatically and identified in unprepared speech. The experiment has determined that these intonemes assist to complete the thought and understand it, influence on listener's emotions and achieve pragmatic goals.

The role of anthropocentric direction is significant in shaping cognitive understanding of the human environment, defining the functions of the language in the course of the cognition development today. Therefore, people use language symbols to understand each other, arise interest and set communicative situation. This use is realized by pragmatics where the units of intonation serve to convey the meaning of a word. This means pragmatics takes place between the sender and recipient in speech situation to provide impact on each other for a specific purpose which contributes to the execution of a perlocutive act. Consequently, pragmatics provides the relationship between the speaker and the listener, background knowledge, involvement of recipient in thoughts, his attitude to the real world and distinguishing speech situations through intonation units. The ideas given by intonation units are used for different purposes. Speech is clear and coherent owing to speaker's cognition, the breadth of his knowledge and recognized by the intonation. Every thought appears in the course of the word and varies according to the context of the speech. According to the research, the relationship between the sender and the recipient is determined by intonation and varied to different indicators such as desire, wish, doubts, asking specific questions and ability to think. Moreover, the syntagma of thought and emotion is highlighted, the signs of influence on the listener are noticed, and the exact meaning of the thought is revealed. Especially in free unprepared speech, the pace sometimes slows down during important thoughts, but sometimes it gets faster. It is observed that in case of unprepared speech, words are often contracted and swallowed, according to the principle of shortening, to save time.

\section{Discussions}

It was found that as the source of the experimental research was the official contact, the intonemes of the strict imperative and the polite imperative, the intonemes of the general question and the special question were neutralized, common signs of the tonal indicator of intoneme signs were revealed, and it turned out that the signs of one shifted to the other. Particularly, we found in the study that syntagma expressed in the form of strict commands are like polite ones, and the tonal indicator is common to both strict and polite types. During the research it was observed that not only the two speakers, but also the viewers have an influence on discourse. It was sometimes noticed that there are viewers or audience as a listener and an observer except the addresser and the addressee (Farahani \& Kaleybar, 2019; Mguwata, 2020).

Example: ...ozdorining gozi tusken osynday kongili tolmaytyn zharnamalar bolsa, bizding galalyq "Til basqarmasyna" myna zhetpis bir alpys bes togsan degen telefondaryna habarlasyp aituyna bolat. Biz arqyly ony retteuge bolat - from this example we noticed that there is a purpose of not only influencing the audience, but also exchanging information.

The process of unprepared speech should be considered in the context of an illocutionary act that occurs between an addresser and an addressee, because they form goal-directed thinking via influence on each other's intentions while speaking. Pragmatics is subdivided into the subject of speech, the relation of the addressee, the relation of the speaker to the addressee, the speech situation. The strength of the speaker's influence and its impact on the listener is expressed via the intoneme of general question (err.r. gordingiz be? sonda garangyz?) in speech involving the addresser and the addressee, as the aim of the addresser is not asking the direct question but the persuasion of the addressee. And the speaker (addresser) engages the listener as well as stimulates the conversation by expressing his thoughts. It is a pragmatic unit that implements the P. Grice's cooperative principle. That is, it has the power of influence and opens the way for the next flow of words through emotions (Madarova \& 
Garcia Laborda, 2020). It has also been established during the experiment that the duration of the hesitative and vocalized pause (one of the components of intonation) is long.

It is speakable of the fact that we have problems with generalization of the idea which we encounter in the process of word formation and vocabulary so as not to interrupt the conversation. To find a word to convey the speaker's thoughts and not to break between syntaxes, we pronounce sounds that arise during unprepared speech through hesitation pause (Kubieva et al., 2021). The speaker tries to generalize his thoughts internally, so that the receiver can understand them. The intonation of counting in speech was particularly prominent in sending message, because the addresser transmitted each piece of information separately and separated each word component with a slower intonation. It shows that the speaker is trying to convey information to the listener by chaining more than one message. When we pronounce counting intonation, the pitch of the voice and the melody are pronounced in parallel, and the inaccurate intonemes, on the contrary, increase the pitch with a decrease in the intensity (ArabZouzani, Pahlavannejadb \& Seyyedi, 2019).

In experimental research, we noticed that even in 8 parameters of intonation, the intensity increased during unprepared speech, especially in accurate intonation, the end of the word is swallowed, that is, the acceleration of the temporal parameter to save time (Kondrateva, Sabirova, \& Plotnikova, 2018). It has been observed that the influence and role of intonation in speech communication is significant, and that the components of intonation (melody, voice intensity, tempo, pause, tone range, voice tone) are particularly pronounced during speech. It has been noticed that the role of intonation components is enhanced especially in unprepared speech in the pragmatic task, and intonemes are pronounced in several variants depending on the speech situation (Ciobanu, 2018).

\section{Conclusions}

Pragmatics seeks to use language characters in the process of internal thinking of the sender and the recipient in unprepared speech, whereas intonation determines its function in the outward way of delivery to the recipient. An experimental study revealed that the meaning of a word flow through intonation in unprepared speech is generated by explicit or implicit goals. In the study, the tone parameter changes rapidly during unprepared speech according to Peshkovsky's "Law of Equality". When the grammatical methods are obscured, the intonation methods become stronger and complement each other.

From the results of the study, it is concluded that during unprepared speech, a flow of speech arises between the sender and the recipient, which opens the way for more general understanding, also reflecting the awareness of the world around the listener to gain new information. It testifies to the fact that every new information generated between the sender and the recipient is a frame.

We have concluded that intonation, as a linguistic phenomenon, lies in the core of pragmalinguistics and serves the full fulfillment of the pragmatic goal in unprepared speech.

\section{References}

Al-Eryani, A. A. (2007). Refusal strategies by Yemeni EFL learners. The Asian EFL Journal, 9(2), 1934. https://asian-efl-journal.com/June_2007_EBook_editions.pdf\#page=19

Amanbayeva, A., \& Zhumabaeva, Zh. (2017). Creating speech synthesis using prosodic methods // peer-reviewed scientific journal Uneversium: philology and art history. - №8 (42).

Amanbayeva, A. Zh. (2012). Pragmalinguistic nature of intonation units (experimental phonetic research). - Almaty, 2012. - p. 176 
ArabZouzani, M. A., Pahlavannejadb, M. R., \& Seyyedi, H. (2019). The investigation of mood and modality in the first letter of Nahj al-Balagheh based on the interpersonal metafunction of Halliday's systemic functional grammar. International Journal of New Trends in Social Sciences, 3(2), 17-25. https://doi.org/10.18844/ijntss.v3i2.3817

Arutyunova, N. D. (1990). Discourse//Linguistic encyclopedic dictionary. M.: Sov. Encyclopedia, 136137.

Astuti, D. A., \& Chandra, O. H. (2021). Speech Acts and the Common Problems Involved in a Humor Text. Culturalistics: Journal of Cultural, Literary, and Linguistic Studies, 5(1), 65-72. https://ejournal2.undip.ac.id/index.php/culturalistics/article/view/11470

Baitursynov, A. (1992). Language lessons. Almaty: Ana tili, - p. 448

Bazarbaeva, Z. M. (2014). Intonation of Kazakh speech. - Lap Lambert Academic Iublishing. Saarbrucken. - p. 188.

Bazarbayeva, Z. M. (2016). Problems of segmental and supersegmental phonetics. - Almaty, 2016. p. 746

Bazarbayeva, Z., Ospangazieva, N., Sadykova, R., Zhalalova, A., \& Zhauynshiyeva, Z. (2018). Description of One-dimensional and Multi-dimensional Distinctive Features in the Kazakh Phonology. An Acad Bras Cienc, 90(1 Suppl 2).

Bazarbayeva, Z. M. (2008). Kazakh intonation - Almaty, Dayk-Press.

Bazarbayeva, Z. M. (2012). Basics of Kazakh phonology - Almaty. - p. 120

Bazarbayeva, Z. M., Zhalalova, A. M., \& Ormakhanova, Y. N. (2015). Universal Properties of $\begin{array}{lllll}\text { Intonation } \quad \text { Components. } & \text { Rev. } & \text { Eur. } & \text { Stud., } & 7,\end{array}$ https://heinonline.org/HOL/LandingPage?handle=hein.journals/rveurost7\&div=200\&id=\&page=

Bazarbayeva, Z. M., Zhalalova, A. M., Ormakhanova, Y. N., Ospangaziyeva, N. B., \& Karbozova, B. D. (2016). Intonational Division of a Speech Flow in the Kazakh Language. International Journal of Environmental and Science Education, 11(10), 3669-3678. https://eric.ed.gov/?id=EJ1114719

Bazarbayeva, Z., Zhunisbek, A., \& Malbakov, M. (2014). Phonological foundations of the transition Kazakh alphabet to Latin graphics. Life Science Journal, 11(9), 147-150. http://www.lifesciencesite.com/lsj/life1109s/027_25142life1109s14_147_150.pdf

Bizakov, S. (2000). Dictionary of variants words. - Almaty: Bilim, 2000. - p. 320

Calandruccio, L., Porter, H. L., Leibold, L. J., \& Buss, E. (2020). The clear-speech benefit for schoolage children: speech-in-noise and speech-in-speech recognition. Journal of Speech, Language, and Hearing Research, 63(12), 4265-4276. https://doi.org/10.1044/2020_JSLHR-20-00353

Ciobanu, N. R. (2018). Language and language disorders. New Trends and Issues Proceedings on Humanities and Social Sciences, 5(1), 200-207. https://doi.org/10.18844/prosoc.v5i1.3473

Deacu, A., Kilyeni, S., \& Barbulescu, C. (2018). Correction techniques for language disorders. International Journal of Learning and Teaching, 10(3), 292-299. https://doi.org/10.18844/ijlt.v10i3.1039

Farahani, M. V., \& Kaleybar, N. M. (2019). Embracing an improved technique of analyzing Persian translations: A case study of waiting for Godot. International Journal of Current Innovations in Interdisiplinary Scientific Studies, 3(2), 16-27. https://un-pub.eu/ojs/index.php/IJCISS/article/view/5281 
Gizdatov, G. G., \& Sopiyeva, B. A. (2018). Discourse and identity in the medial space of Kazakhstan. Медиаобразование, (4). https://cyberleninka.ru/article/n/discourse-and-identity-in-the-medialspace-of-kazakhstan

Goikhman, O. Ya., \& Nadezhdina, T. M. (1997). Basics of speech communication. - M.: - p. 269

Grushevskaya, T. G., Popkov V. D., \& Sadokhin, A. P. (2003). Basics of intercultural communication. -M.: UNITI-DANA, 2003. - p. 352

Humboldt, W. (1999). On language: On the diversity of human language construction and its influence on the mental development of the human species. https://philpapers.org/rec/HUMOLO

Joudi, N. S. (2019). Gender leadership styles and linguistic practices: The case of Lebanese International University coordinators. International Journal of Innovative Research in Education, 6(2), 47-61. https://doi.org/10.18844/ijire.v6i2.4362

Kavilova, T., Umrzoqova, G., \& Inomov, U. (2020). Theory of the concept of speech act. Аpxuв Hаучных Публикаций JSPI, 1-293. edu.uz/index.php/archive_jspi/article/view/3806

Khajayeva, Z., Stambekova, A., Gazikhanova, Z., Smagulova, G., \& Makhanbetjanovna, S. R. (2021). Primary school teacher candidates' views on multilingual concepts: A perspective of learning technology. World Journal on Educational Technology: Current Issues, 13(1), 01-09. https://doi.org/10.18844/wjet.v12i4.5184

Klyuev, Ye. V. (1998). Speech communication. - p. 224 Russian language and culture of speech. Under the editorship of Professor V.I. Maksimova - M.: 2000. p. 411

Kondrateva, I., Sabirova, D., \& Plotnikova, N. (2018). Subjectivity functions in reflexive and intercultural process of linguistic development. Cypriot Journal of Educational Sciences, 13(4), 529-536. https://doi.org/10.18844/cjes.v13i4.3858

Korolyov, I., \& Domylivska, L. (2020). Mentality and national character as semiotic regulators of communicative behavior. Journal of History Culture and Art Research, 9(1), 354-364. http://dx.doi.org/10.7596/taksad.v9i1.2355

Kubieva, V., Sagiyeva, A., Sagiyeva, A., Salimgerey, Z., \& Baiseitova, M. (2021). Multilingualism is a trend in the development of modern Kazakhstan. Global Journal of Sociology: Current Issues, 11(1), 40-44. https://doi.org/10.18844/gjs.v11i1.5480

Legas, A. M., \& Mengistu, A. A. (2018). The practice and guidance and counseling in Amhara region Ethiopia. Global Journal of Guidance and Counseling in Schools: Current Perspectives, 8(3), 119-127. https://doi.org/10.18844/gjgc.v8i3.3605

Lukyanova, V., \& Koloskova, O. (2020). Pragmatic potential of onomatopoeia in animated movies for children. Global Journal of Foreign Language Teaching, 10(1), 58-64. https://doi.org/10.18844/gjflt.v10i1.4482

Lvov, M. R. (2000). Basics of speech theory. - M.. - p. 248

Madarova, S., \& Garcia Laborda, J. (2020). Seven common misconceptions in bilingual education in primary education in Spain. Cypriot Journal of Educational Sciences, 15(2), 358-368. https://doi.org/10.18844/cjes.v15i2.4605

Matzler, A. A. (1990). Pragmatics of communicative units. - Kishenev.: 1990. - p. 103 
Mavasoglu, M. (2018). Readability, referential cohesion and interaction in texts of websites, textbooks and workbooks for French language learning. World Journal on Educational Technology: Current Issues, 10(2), 88-103. https://doi.org/10.18844/wjet.v10i2.3419

Mguwata, T. (2020). Psychosocial challenges and coping strategies of caregivers with family members under palliative care in Mufakose, Zimbabwe. Global Journal of Psychology Research: New Trends and Issues, 10(2), 210-220. https://doi.org/10.18844/gjpr.v10i2.4797

Minyar-Beloroucheva, A., Sergienko, P., Vishnyakova, E., \& Vishnyakova, O. (2020). Semantic and cognitive communicative aspects of abbreviation in the modern English discourse varieties. International Journal of English Linguistics, 10(1), 26-36. https://doi.org/10.5539/ijel.v10n1p26

Mok, J. (2010). The new role of English language teachers: developing students' critical thinking in Hong Kong secondary school classrooms. The Asian EFL Journal Quarterly, 12(2), 262-287. http://70.40.196.162/PDF/June-2010.pdf\#page=262

Natividad, M. R. A., \& Batang, B. L. (2018). Students' Perceptual Learning Styles and Attitudes toward Communicative Language Teaching. TESOL International Journal, 13(4), 104-120. https://eric.ed.gov/?id=EJ1244108

Posner, R. (2019). Syntactics, Semantics, and Pragmatics Revisited half a Century after their Introduction by Charles W. Morris. In Signs of Humanity/L'homme et ses signes, (pp. 1349-1354). De Gruyter Mouton. https://doi.org/10.1515/9783110854572-168

Theodorou, P., \& Meliones, A. (2019). Developing apps for people with sensory disabilities, and implications for technology acceptance models. Global Journal of Information Technology: Emerging Technologies, 9(2), 33-40. https://doi.org/10.18844/gjit.v9i2.4431

Uzunboylu, H., Hürsen, Ç., Özütürk, G., \& Demirok, M. (2015). Determination of Turkish University students' attitudes for mobile integrated EFL classrooms in North Cyprus and scale development: ELLMTAS. Journal of Universal Computer Science, 21(10), 1283-1296 https://doi.org/10.3217/jucs-021-10-1283

Vygotsky L.S. (1934). Thinking and Speech // Psychological Research. - M. - p. 325

Yeldham, M. (2018). Viewing L2 captioned videos: what's in it for the listener?. Computer Assisted Language Learning, 31(4), 367-389. https://doi.org/10.1080/09588221.2017.1406956

Zand-Moghadam, A., \& Adeh, A. (2020). Investigating pragmatic competence, metapragmatic awareness and speech act strategies among Turkmen-Persian bilingual and Persian monolingual EFL learners: A cross-cultural perspective. Journal of Intercultural Communication Research, 49(1), 22-40. https://doi.org/10.1080/17475759.2019.1705876

Zhumanbekova, N. Z., Bentyaa, Y. V., \& Dzharbulova, A. (2018). The figurative idioms of English, German and Kazakh in contrast. Contemporary Educational Researches Journal, 8(3), 83-88. https://doi.org/10.18844/cerj.v8i3.589

\section{AUTHOR BIODATA}

Bazarbayeva Zeinep, Doctor of Philology, Professor, Corresponding Member of the National Academy of Sciences of the Republic of Kazakhstan. Graduated from Moscow State Institute of Foreign Languages named after Maurice Toreza in 1975. Defended thesis on "Intonation of introductory units in various types of languages (based on French, Kazakh and Russian languages)" in 1983; Doctoral dissertation on the topic "Intonation system of the Kazakh language" in 1997. Professor of Philology since 2003. Corresponding member of NAS RK since 2013. Works at the Institute of Linguistics named after A. Baitursynov as the main researcher, specialist in 
general, typological, Turkic linguistics. She has been participating in leading research projects on segment and super-segment phonetics, historical phonology, intonology, communicative syntax, applied linguistics for 20 years. She is the founder of a scientific school on Kazakh intonology and phonology in the Republic of Kazakhstan. She has been a member of the evaluation committee for research projects submitted to the Science Foundation competition for the formation of fundamental research programs, a member of the Expert Council of the Higher Attestation Committee and the editor-in-chief of the Republican scientific journal Tiltanym (Linguistics). Published more than 250 scientific works, including 10 monographs, 5 dictionaries, study guides.

Amanbayeva A. Zh, has been working as a performer of fundamental and applied research since 2003. In 20152017, he led the Grand work" synthesis of Kazakh speech: the formation of a phonetic Corpus". About 50 articles have been published in scientific journals and conferences. In 2013, the monograph" Pragmalinguistic character of intonation units " was published. A. Amanbayeva has been working on fundamental and applied research grant projects on Segmental and suprasegmental phonetics. The main areas of study are phonetics, intonation, pragmalinguistics, discourse, speech communication. He also conducted research on speech synthesis in order to connect modern techniques and technologies with linguistics. At the moment, the adaptation of the computer language to the needs of a person, that is, computer speech, is being gradually developed. There are very few studies related to speech synthesis in Kazakh linguistics. After all, this is not only the work of journalists, especially phonetic specialists, but also a large-scale work together with computer specialists. Therefore, adapting a human language to a computer program in its true form will only be effective as a result of many years of research. Therefore, A. Amanbayeva conducts research in this direction.

Zhumabayeva Zhanar, works as a senior researcher at the Institute of Linguistics named after A. Baitursynov. In accordance with the basic research program, he conducts research on the topic "history of vowels". In the works of Zh.Zhumabayeva, the mechanisms of the system of vowel development are considered on the basis of Orkhon-Yenisei written monuments and linguistic data of Turkic languages. Also, the ways of formation and development of the system of sounds in the Turkic language are determined on the basis of the process of universal phonologization, and the mechanism of transformation of allophones into phonemes is determined. He also made a significant contribution to the publication of the work" life and work of M. Balakayev", published in the series" uly Dala tulgalary". Zh.T. Zhumabayeva has been participating in fundamental and applied research since 2007 as a performer. He has published many scientific articles in scientific journals and international conferences, and has published a monograph "historical foundations of vowels in Turkic languages".

Zhalalova Akshay, Doctor of philosophy ( $\mathrm{PhD})$, associated professor of the Kazakh National Women's Teacher Training University, was born in the South of Kazakhstan, graduated from Almaty Pedagogical Institute of Foreign Languages. She began her career at school as a language teacher. She defended Doctoral Thesis on the theme "Discursive description of Intonation (on the materials of Kazakh and English languages)" in 2016. She is a disciple of Bazarbayeva Z., founder of a scientific school in Kazakh Intonology and Phonology in the Republic of Kazakhstan. There are about 40 articles have been published in scientific journals and in conference proceedings, as well as 3 training manuals, 1 glossary. She has been participating in different fundamental and applied research grant projects of the Ministry of Education and Science of the Republic of Kazakhstan as a senior and leading scientific researcher since 2015. Since 2019 she has been working as the Head of the Department of Methods of Teaching Foreign Languages at the Institute of the Kazakh language and World languages, as well as the associated professor of at Kazakh National Women's Teacher Training University. 